\title{
REVIEW
}

\section{Can ventilation in healthcare facilities prevention of infection COVID-19?}

\author{
Abdolmajid Fadaei \\ Department of Environmental Health Engineering, School of Health, Shahrekord University of Medical Sciences, Shahrekord, Iran
}

\section{Check for updates}

Correspondence to: Abdolmajid Fadaei, Department of Environmental Health Engineering, School of Health, Shahrekord University of Medical Sciences, Shahrekord, Iran; E-mail: ali2fadae@yahoo.com

Received: May 14, 2021;

Accepted: September 3, 2021;

Published: September 7, 2021

Citation: Fadaei A. Can ventilation in healthcare facilities prevention of infection COVID-19?. Health Environ, 2021, 2(1): 96-102

https://doi.org/10.25082/HE.2021.01.004

Copyright: (C) 2021 Abdolmajid Fadaei. This is an open access article distributed under the terms of the Creative Commons Attribution License, which permits unrestricted use, distribution, and reproduction in any medium, provided the original author and source are credited.

\begin{abstract}
Currently, (2019-2020) COVID-19 global pandemic is caused by a member of the Coronaviridae group. Some human viruses are spread from human to human by way of droplets or aerosols, but fewer viruses are persistently airborne in transmission, and the healthcare-associated epidemic of airborne viral infection are restricted to very few surrogates The prevention of air pollutants (i.e., biological, particles, chemicals, and smoke) at the resource has the highest efficiency to keep safe air. In addition, it is one of the most efficient tools (i.e. the second one) for preventing inside air pollution through ventilation. To our aim was to perform a rapid literature review to answer the following question: does ventilation in healthcare facilities prevention of infection COVID-19? We systematically searched Embase, PubMed/MEDLINE, Scopus, PubMed Central (PMC), Google Scholar databases as well as medRxiv by using the following key-words: 'COVID-19', 'healthcare settings', 'prevention', 'ventilation', 'Hospital, 'Infection', and 'Air changes per hour. A total of 26 eligible articles were identified. The literature denotes that temperature, relative humidity, and ventilation and air conditioning systems have beneficial effects to prevent COVID-19 infection. Thus, based on recommendations of $\mathrm{CDC}$, WHO, and other studies effective ventilation is the most important transmission of respiratory disease control strategy, specially COVID-19.
\end{abstract}

Keywords: corona viruses infections, prevention and control, ventilation

\section{Introduction}

Initially, COVID-19 that begun at the end of 2019 has turned into a pandemic [1]. According to the evidence, its main ways of transmission are person-to-person and viral droplets $(>5-10$ $\mu \mathrm{m}$ in diameter) of infected patients, or sings at short distances, commonly $<1-2 \mathrm{~m}$. However, there are doubts about its transmission through $(<5 \mu \mathrm{m}$ in diameter), remaining infectious when suspended in the air over long distances and time [2,3]. It worth noting that personal hygiene and avoiding infected surfaces is of crucial importance.Ventilation is a principal infectious disease prevention method in health care centers and other facilities [4], using a suitable HVAC (heating, ventilation, and air conditioning) system could be mitigated virulence of SARS-CoV-2

Currently, indoor air quality (IAQ) has achieved more consideration because people are spending more time at home (70-90\%), the impact of outdoor source on IAQ, and existence of various kinds of pollutants such as Total volatile organic compounds (TVOCs), household cleaning products, disinfectant sprays, particulate matter (PM), $\mathrm{CO}_{2}$, and bioaerosols agents in IAQ [5]. There are several parameters, such as origins, building construction and materials, air conditioning and its speed, inhabitant practice and functions that influence the IAQ [6]. This systematic review intended to investigate does ventilation in healthcare facilities prevention of infection COVID-19?. The spread of epidemics is associated with air pollutants (carbon monoxide, sulfur oxides, nitrogen oxides, ground-level ozone, particulate matter, and lead, other pollutants (Polycyclic Aromatic Hydrocarbons (PAHs), Volatile Organic Compounds (VOCs), and Dioxins. Global climate change (greenhouse gases, ozone-depleting), and climatological factors (e.g., wind speed, temperature, humidity) [7], for example, as the virus has a lipid envelope, its survival is longer in areas with lower $(<50 \%)$ relative humidity $(\mathrm{RH})$ than $\mathrm{RH}>80 \%$ [4]. Ventilation has a crucial role in preventing contagious diseases in healthcare facilities as well as other settings. Therefore, this fast literature review tries to provide adequate knowledge and strategies for ventilation methods and control and prevention strategies.

\section{Methods}

Following a systematic review design, this research was conducted to evaluate can ventilation in healthcare facilities prevention of infection COVID-19? In total 25 articles were found 
to be eligible for a full evaluation ,then focuses on ten $(N=10)$ studies. We systematically searched databases of Scopus, ISI, Web of Science, Google Scholar, PubMed (MEDLINE), World Health Organization, and American Centers for Disease Control (CDC) and Prevention using MeSH (Medical Subject Headings) keywords for the period of December 2019 to April 2021. Descriptive statistics is performed categorizing. Hence, using appropriate keywords ("Coronaviruses" OR "CoV" OR "Human Coronaviruses "OR "HCoV" OR "nCov" OR "Novel Coronaviruses " OR "2019 Novel Coronavirus" OR "Covid-19” OR "2019-nCoV” OR "Severe Acute Respiratory Syndrome-Coronaviruses-2”OR“SARS-COV-2”) AND (“Air pollution” OR "Air pollution"OR"Ventilation" OR "Air changes per hour"OR"healthcare facilities") AND ("Hospital);( "indoor air quality AND COVID-19"); ("Prevention Methods" OR "Infection Prevention and Control") the abovementioned databases were searched. Information on the authors' name, type study, study remarks, type of setting, and main variables parameters like temperature, relative humidity, and type of ventilation and outcomes were collected. The quality of identified articles was evaluated using the PRISMA Preferred Reporting Items for Systematic Reviews and Meta-analyzes [8]. There are several methods for measurement of ventilation rate such as: Air changes per hour, volumetric airflow per person, volumetric airflow per floor area, percent outdoor air intake, and $\mathrm{CO}_{2}$ concentration. In this study used to air changes per hour volumetric airflow per person, percent outdoor air intake, and $\mathrm{CO}_{2}$ concentration methods.

Air changes per hour one significant change relates to the ventilation recommendations for patient rooms, values were estimated as follows [9]:

$$
\mathrm{t}_{2}-\mathrm{t}_{1}=-\left[\ln \left(\mathrm{C}_{2} / \mathrm{C}_{1}\right) /(\mathrm{Q} / \mathrm{V})\right] \times 60
$$

with $\mathrm{t}_{1}=0$, where

$\mathrm{t}_{1}=$ initial time point in minutes;

$\mathrm{t}_{2}=$ final time point in minutes;

$\mathrm{C}_{1}=$ inlet concentration of contaminant;

$\mathrm{C}_{2}=$ outlet concentration of contaminant;

$\mathrm{C}_{2} / \mathrm{C}_{1}=1$ - (removal efficiency/100);

$\mathrm{Q}=$ air flow rate in cubic feet/hour;

$\mathrm{V}=$ room volume in cubic feet;

$\mathrm{Q} / \mathrm{V}=\mathrm{ACH}$.

In the discussion section, we discussed the most important findings in three parts included: indoor air ventilation, indoor air relative humidity, and indoor air temperature.

\section{Results}

Of the 10 articles, $60 \%$ (4), $20 \%$ (2), and $20 \%$ (2) were based on the simulation, experimental, and observational methods, respectively (see Figure 1). These articles were from health care/hospital (4), public buildings (3), Residential places (1), dormitory (1), and offices (1). The main results are provided in Table 1 . Based on results this study, two articles mentioned that SARS-COV-2 can be reduced by ventilation in the air hospitals, while eight noted the ventilation effect in closed areas. Demonstrated that air changes/hour and outline of ventilation according to guidelines and standards of CDC and those published for controlling infection at healthcare settings. (see Table 2 and 3 )

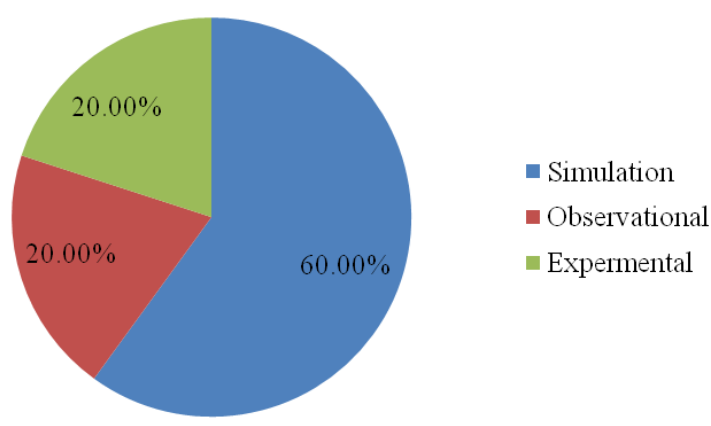

Figure 1 Condition type of design researches 
Table 1 Most important characteristics of reviewed papers

\begin{tabular}{|c|c|c|c|}
\hline Type study & Type setting & Remarks & Reference \\
\hline Simulation & Public buildings & $\begin{array}{l}\text { A minimum RH standard of } 40 \% \text { for populated spaces not only decrease the effect of the virus, } \\
\text { but also can decrease the effect of more viral infections, both arid and moist places. }\end{array}$ & [28] \\
\hline Simulation & Public buildings & There is a major and firm possibility of airborne spread of COVID-19 in indoor air ambient & [38] \\
\hline Simulation & Hospitals & Ventilation has a major impact on SARS-CoV-2 spread & [39] \\
\hline Experimental & Residential Indoor & $\begin{array}{l}\text { Action programs should be promoted for the reinstatement or enhancement of the filtration } \\
\text { systems of the air-conditioning and heating systems in houses }\end{array}$ & [5] \\
\hline Simulation & Patient Rooms & Increase ventilation rates were not causes reduce aerosol concentrations & [40] \\
\hline Experimental & Hospitals & $\begin{array}{l}\text { The few COVID-19 studies did not provide adequate indication that the virus may be spread } \\
\text { by HVAC systems. }\end{array}$ & [3] \\
\hline Observational & Dormitory & $\mathrm{CO}_{2}$ mean level was $1230 \pm 408 \mathrm{ppm}$ and $1492 \pm 837 \mathrm{ppm}$ in the two dormitory buildings. & [41] \\
\hline Simulation & Public buildings & $\begin{array}{l}\text { Use of engineering controls in populated spaces such as: separating infected individuals, } \\
\text { opening windows and doors, and using moveable air-cleaning devices when practicable }\end{array}$ & [42] \\
\hline Observational & Health care centers & $\begin{array}{l}\text { Simple changes in hospital structure noticeably enhanced natural ventilation, and seriously } \\
\text { decreased air borne infection risk at little cost }\end{array}$ & [43] \\
\hline Simulation & Offices & $\begin{array}{l}\text { Relationship among air conditioning and sick building syndrome (SBS) signs in various } \\
\text { rooms, where higher ventilation rates, up to about } 25 \mathrm{l} / \mathrm{s} \text { per capita, are related with decreased } \\
\text { symptoms }\end{array}$ & [44] \\
\hline
\end{tabular}

Table 2 Air changes/hour $(\mathrm{ACH})$ and time required for airborne-contaminant removal by efficiency [36]

\begin{tabular}{ccc}
\hline $\mathrm{ACH}$ & $\begin{array}{c}\text { Time (mins) required for } \\
\text { removal: } 99 \% \text { efficiency }\end{array}$ & $\begin{array}{c}\text { Time (mins) required for } \\
\text { removal: } 99.9 \% \text { efficiency }\end{array}$ \\
\hline 2 & 138 & 207 \\
4 & 69 & 104 \\
6 & 46 & 69 \\
8 & 35 & 52 \\
10 & 28 & 41 \\
12 & 23 & 35 \\
15 & 18 & 28 \\
20 & 14 & 21 \\
50 & 6 & 8 \\
\hline
\end{tabular}

Table 3 Outline of ventilation characteristics in chosen areas of health-care centers [36]

\begin{tabular}{|c|c|c|c|c|c|}
\hline Characteristics & $\begin{array}{c}\text { All room } \\
\text { (includes bronchoscopy suites) }\end{array}$ & Protective environment & Critical care room & $\begin{array}{l}\text { Isolation } \\
\text { anteroom }\end{array}$ & $\begin{array}{l}\text { Operating } \\
\text { room }\end{array}$ \\
\hline Air pressure & Negative & Positive & $\begin{array}{l}\text { Positive, negative, } \\
\text { or neutral }\end{array}$ & $\begin{array}{l}\text { Positive or } \\
\text { negative }\end{array}$ & Positive \\
\hline Room air changes & $\begin{array}{l}\geq 6 \mathrm{ACH} \text { (for existing rooms); } \\
\geq 12 \mathrm{ACH} \text { (fore novation or new } \\
\text { construction) }\end{array}$ & $\geq 12 \mathrm{ACH}$ & $\geq 6 \mathrm{ACH}$ & $\geq 10 \mathrm{ACH}$ & $\geq 15 \mathrm{ACH}$ \\
\hline Sealed & Yes & Yes & No & Yes & Yes \\
\hline Filtration supply & 90\% (dust-spot ASHRAE52.1 1992) & $\begin{array}{l}99.97 \% \text { (Fungal spore filter } \\
\text { at point of use (HEPA at } \\
99.97 \% \text { of } 0.3 \mu \mathrm{m} \text { particles)) }\end{array}$ & $>90 \%$ & $>90 \%$ & $90 \%$ \\
\hline Recirculation & $\begin{array}{l}\text { No (Recirculated air may be used } \\
\text { if the exhaust air is first processed } \\
\text { through a HEPA filter.) }\end{array}$ & Yes & Yes & No & Yes \\
\hline
\end{tabular}




\section{Discussion}

\subsection{Indoor air ventilation}

The results of this study illustrated that there were more researches associated to SARS-COV2 and ventilation in closed spaces. According to results, two papers mentioned that ventilation was not associated with reduced levels of SARS-COV-2 in the air of hospitals, meanwhile, eight papers reported vice versa. Hence, more studies are needed to investigate whether ventilation systems are associated with declined transmission of SARS-COV-2. In healthcare settings, ventilation strategy and air distribution model affect the transmission of contagious diseases.

There are three methods that may be used to ventilate spaces within health-care settings: natural, mechanical and combination (mixed-mode) ventilation. Any decision on climate to use natural, combination or mechanical ventilation should take into account climate, including prevalent wind path, floor plan, need, availability of resources, and the cost of the ventilation system [10].

In health-care settings, the ventilation rate (mechanical method) should be 6-12, ideally $12 \mathrm{ACH}$ for new constructions and mean natural ventilation rate is $160 \mathrm{~L} / \mathrm{s} /$ patient, with a recommended negative pressure differential of $\geq 2.5 \mathrm{~Pa}$ to gurantee air flows from the corridor into the rooms designed for hospitalizing patients $[9,11]$. Ventilation $(>6 \mathrm{ACH})$ can guarantee both negative pressure difference $(>2.5 \mathrm{~Pa})$ and airflow difference $(>56 \mathrm{~L} / \mathrm{s})$ (Table 2) $[12,13]$. Upgrading ventilation of health care centers will dilution and removal potentially infectious aerosols [14]. Inappropriate use of ventilation systems has severe negative effects on transmission of COVID-19 [15]. Effective ventilation is a major technique to prevent expansion of contagious disease [16].

One research demonstrated that the majority of COVID-19 patients infected at home became infected in a cold, air conditioned, arid, and bad-ventilated indoor condition [17]. Masoumbeigi and colleagues mentioned that mechanical air conditioning and natural ventilation are available methods that can be used for air cleaning in hospitals [18]. Masoumbeigi and colleagues and Faridi and colleagues illustrated that ventilation (either mechanical or natural) were applied in healthcare facilities $[18,19]$. Another study by Li and colleagues, various health care center wards were prepared using heating, ventilation and air conditioning (HVAC) systems [20]. A research reported no strong evidence to support the association between COVID-19 air-bore transmission and HVAC systems [21]. Wells-Riley equation contains the major contribution of ventilation:

$$
\mathrm{P}=\frac{n l}{n \mathrm{~S}}=1-\exp \left(-\frac{q \Gamma t s}{Q}\right)
$$

where $n I$ is the expected frequency of patients at room, $n S$ is the frequency of susceptible at room at $t S, n E$ is the number of spreaders 'quanta' (to the mean viral load necessary for infection transmission) at a rate $\gamma i$ (giving the total emission rate $\Gamma=\sum_{i=1}^{n E} \gamma_{i}$ ), $q$ is the time-average volume fluxof exhaled air per person and $Q$ is the volume flux of fresh (clean) air entering the room [22].

\subsection{Indoor air Relative humidity $(\mathrm{RH})$}

According to the evidence, in health care centers, $\mathrm{RH}$ is a major contribution for preventing contagious diseases, as it affects both growth and transfer of airborne of contagious agents $[23,24]$. RH affects the transmission of contagious agents. Suitable RH affects the survivability of: Viruses with lipid envelops (i.e. Influenza virus, Para-Influenza virus, Corona virus, and Varicella zoster virus lower RH (20\%-30\%RH); (b) Viruses non-lipid enveloped (i.e. Adenovirus, Enterovirus, and Rhinoviruses higher RH70\%-90\% RH); (c) Gram-negative bacteria(i.e. Serratia marcescens, Klebsiella, and Proteus vulgaris lower RH ( $<50 \%$ RH): and (d) Airborne grampositive(i.e. Staphylococcus epidermidis, Streptococcus haemolyticus, Bacillus subtilis, and Streptococcus pneumonia bacteria lower RH $(<50 \%$ RH) [25,26]. Nevertheless, it's wellproved that low RH $(<20 \%)$ affects susceptibility to various contagious agents [27].

On the other hand, the low RH negatively affects the ability of the immune system's to cope with microorganisms [28].

Another study by Ahlawat reported that close areas with in dry conditions (humidity $(<$ $40 \%$ ), there is high probability of COVID-19 trransmission [28]. Another study suggested an RH of 30-60\% for healthcare settings [29]. One study reported a negative association between RH (increased from 23.33 to $82.67 \%$ ) and COVID-19 transmission [30]. Biktasheva mentioned that humidity affects COVID-19 transmission [31]. Another study by Huang et al., reported, in conditions with low indoor temperature and high environment temperature, there is a correlation 
between RH and outdoor absolute humidity (AH), which translates into increased COVID-19 transmission [32].

\subsection{Indoor air temperature}

It has a crucial impact on patients' perception from thermal comfort. In other words, uncomfortable temperatures negatively affect the patients' satisfaction, like wakefulness and nervousness, and may result in shaking, inattention, and muscular and joint constriction [26].

Several studies reported creating thermal zones to met various needs of infected cases, and their separate thermal preferences such as: Operating room $24-26^{\circ} \mathrm{C}\left(74.2-78.8^{\circ} \mathrm{F}\right)$, Delivery room $\geq 26^{\circ} \mathrm{C}\left(78.8^{\circ} \mathrm{F}\right)$, Nursery (for infants), around $28^{\circ} \mathrm{C}\left(82.4^{\circ} \mathrm{F}\right)$, Patient room $21-24^{\circ} \mathrm{C}(70$ $\left.75^{\circ} \mathrm{F}\right)$, and Bronchoscopy $20-23^{\circ} \mathrm{C}\left(68-73^{\circ} \mathrm{F}\right)$ [33]. At first days of COVID-19 emergence, the severity of the disease was higher in countries with relatively lower environmental temperature [34]. One research explained that a considerable negative relationship among temperature and outbreak [34].

Thus, based on recommends of CDC, WHO, and other studies effective ventilation is of crucial importance for control strategies developed for transmission of respiratory diseases, specially COVID-19 $[9,35,36]$. There are many researches about temperature and humidity such as: temperature should range from 17 to $28^{\circ} \mathrm{C}$, and the $\mathrm{RH}$ should be 40 to $70 \%$ [37], the best humidity should range from 40 to $60 \%$ at workplace and a general indoor temperature of $21-23^{\circ} \mathrm{C}$ [37]. All of these relevant research agrees with the results of the current study.

\section{Conclusion}

There are well-established evidence to propose that the temperature, relative humidity, and ventilation and air conditioning systems (ACSs), have beneficial effects to prevent COVID-19 infection.

Caution should be taken when setting temperature and relative humidity, using a step-by-step process. The findings propose greatly that rather than natural ventilation (e.g. windows), use of artificial ventilation and ACSs may cause better IAQ in health-care centers and close places and reducing bioaerosols and PM exposure in the indoor air of health-care centers and close places.

Researchers, health decision-makers, policy-makers, to reduce the risk of vulnerability of people to future epidemics and pandemics, can act on six factors basic strategy of control COVID-19 include: hand hygiene, social distancing, screening and case finding, isolation and separating, decontamination and disinfection, and effective ventilation. Items aforementioned will more protect healthcare staffs, patients and the general popular. Our Results confirm that improving ventilation of populated places and hospitals will dilute and get out potentially infectious aerosols.More study and investigation are necessary to investigate the role of outdoor and indoor air quality management, particularly ventilation. Hence, to find whether ventilation systems can decline the spread of COVID-19, which requires more extensive research.

\section{Availability of data}

All data generated or analyzed during this study are included within the Article.

\section{Conflict of interests}

The author declares no conflict of interests.

\section{Acknowledgements}

The author thanks Shahrekord University of Medical Sciences.

\section{References}

[1] Xu K, Cui K, Young L, et al. Impact of the COVID-19 event on air quality in central China. Aerosol Air Quality Research, 2020, 20: 915-929. https://doi.org/10.4209/aaqr.2020.04.0150 
[2] Sadeghi M, Fadaei A and Ataee M. Assessment of hospitals medical waste management in Chaharmahal and Bakhtiari Province in Iran. Archives of Agriculture and Environmental Science, 2020, 5(2): $157-163$ https://doi.org/10.26832/24566632.2020.0502011

[3] Chirico F, Sacco A, Bragazzi NL, et al. Can air-conditioning systems contribute to the spread of SARS/MERS/COVID-19 infection? Insights from a rapid review of the literature. International Journal of Environmental Research and Public Health, 2020, 17(17): 6052 https://doi.org/10.3390/ijerph17176052

[4] Correia G, Rodrigues L, Da Silva MG, et al. Airborne route and bad use of ventilation systems as non-negligible factors in SARS-CoV-2 transmission. Medical Hypotheses, 2020, 141: 109781. https://doi.org/10.1016/j.mehy.2020.109781

[5] Domínguez-Amarillo S, Fernández-Agüera J, Cesteros-García S, et al. Bad air can also kill: residential indoor air quality and pollutant exposure risk during the COVID-19 crisis. International Journal of Environmental Research and Public Health, 2020, 17(19): 7183. https://doi.org/10.3390/ijerph17197183

[6] Harbizadeh A, Mirzaee SA, Khosravi AD, et al. Indoor and outdoor airborne bacterial air quality in day-care centers (DCCs) in greater Ahvaz, Iran. Atmospheric Environment, 2019, 216: 116927. https://doi.org/10.1016/j.atmosenv.2019.116927

[7] Manisalidis I, Stavropoulou E, Stavropoulos A, et al. Environmental and health impacts of air pollution: A review. Frontiers in Public Health, 2020, 8: 14. https://doi.org/10.3389/fpubh.2020.00014

[8] Moher D, Liberati A, Tetzlaff J, et al. Preferred reporting items for systematic reviews and metaanalyses: the PRISMA statement. International Journal of Surgery, 2010, 8(5): 336-341. https://doi.org/10.1016/j.ijsu.2010.02.007

[9] Organization WH. Infection prevention and control during health care when novel coronavirus ( $\mathrm{nCoV}$ ) infection is suspected: interim guidance, 25 January 2020.

[10] Organization WH. Infection prevention and control during health care when COVID-19 is suspected: interim guidance, 19 March 2020. World Health Organization, 2020.

[11] Feng Y, Marchal T, Sperry T, et al. Influence of wind and relative humidity on the social distancing effectiveness to prevent COVID-19 airborne transmission: A numerical study. Journal of Aerosol Science, 2020, 147: 105585 . https://doi.org/10.1016/j.jaerosci.2020.105585

[12] Jayaweera M, Perera H, Gunawardana B, et al. Transmission of COVID-19 virus by droplets and aerosols: A critical review on the unresolved dichotomy. Environmental Research, 2020, 188: 109819. https://doi.org/10.1016/j.envres.2020.109819

[13] Control CfD, Prevention. Scientific brief: SARS-CoV-2 and potential airborne transmission, 2020.

[14] Somsen GA, van Rijn C, Kooij S, et al. Small droplet aerosols in poorly ventilated spaces and SARS-CoV-2 transmission. The Lancet Respiratory Medicine, 2020, 8(7): 658-659. https://doi.org/10.1016/S2213-2600(20)30245-9

[15] Correia G, Rodrigues L, Silva M, et al. Airborne route and bad use of ventilation systems as nonnegligible factors in SARS-CoV-2 transmission. Medical Hypotheses, 2020, 141: 109781. https://doi.org/10.1016/j.mehy.2020.109781

[16] Covaci A. How can airborne transmission of COVID-19 indoors be minimized? Environment International, 2020, 142: 105832 https://doi.org/10.1016/j.envint.2020.105832

[17] Habeebullah TM, Abd El-Rahim IH and Morsy EA. Impact of outdoor and indoor meteorological conditions on the COVID-19 transmission in the western region of Saudi Arabia. Journal of Environmental Management, 2021, 288: 112392. https://doi.org/10.1016/j.jenvman.2021.112392

[18] Masoumbeigi H, Ghanizadeh G, Arfaei RY, et al. Investigation of hospital indoor air quality for the presence of SARS-Cov-2. Journal of Environmental Health Science and Engineering, 2020, 18(2): 1259-1263. https://doi.org/10.1007/s40201-020-00543-3

[19] Faridi S, Niazi S, Sadeghi K, et al. A field indoor air measurement of SARS-CoV-2 in the patient rooms of the largest hospital in Iran. Science of the Total Environment, 2020, 725: 138401. https://doi.org/10.1016/j.scitotenv.2020.138401

[20] Li Y, Fan Y, Jiang L, et al. Aerosol and environmental surface monitoring for SARS-CoV-2 RNA in a designated hospital for severe COVID-19 patients. Epidemiology \& Infection, 2020, 148: 1-14. https://doi.org/10.1017/S0950268820001570

[21] Belingheri M, Paladino ME, Riva MA. COVID-19: health prevention and control in non-healthcare settings. Oxford University Press UK, 2020. https://doi.org/10.1093/occmed/kqaa048

[22] Bhagat RK, Wykes MD, Dalziel SB, Linden P. Effects of ventilation on the indoor spread of COVID19. Journal of Fluid Mechanics, 2020, 903: F1. https://doi.org/10.1017/jfm.2020.720

[23] Fadaei A. Comparison of environmental health indices of private clinics in Chramahal and Bakhtiari province, Iran. Advances in Environmental Biology, 2014, 8(7): 2335-2338.

[24] Azuma K, Yanagi U, Kagi N, et al. Environmental factors involved in SARS-CoV-2 transmission: effect and role of indoor environmental quality in the strategy for COVID-19 infection control. Environmental Health and Preventive Medicine, 2020, 25(1): 1-16. https://doi.org/10.1186/s12199-020-00904-2 
[25] Ahmadi D and Fadaei A. Efficiency Evaluation of Hospitals Sterilization by Biological and Chemical Methods. Quality of Life, 2021, 20(1-2): 23-30.

[26] Shajahan A, Culp CH, Williamson B. Effects of indoor environmental parameters related to building heating, ventilation, and air conditioning systems on patients' medical outcomes: A review of scientific research on hospital buildings. Indoor Air, 2019, 29(2): 161-176. https://doi.org/10.1111/ina.12531

[27] Dietz L, Horve P, Coil D, et al. 2019 Novel Coronavirus (COVID-19) Pandemic: Built Environment Considerations To Reduce Transmission. Applied and Environmental Science, 2020, 5(2): e00245-20. https://doi.org/10.1128/mSystems.00245-20

[28] Ahlawat A, Wiedensohler A and Mishra SK. An Overview on the role of relative humidity in airborne transmission of SARS-CoV-2 in indoor environments. Aerosol and Air Quality Research, 2020, 20(9): 1856-1861. https://doi.org/10.4209/aaqr.2020.06.0302

[29] Balaras CA, Gaglia AG, Georgopoulou E, et al. European residential buildings and empirical assessment of the Hellenic building stock, energy consumption, emissions and potential energy savings. Building and Environment, 2007, 42(3): 1298-1314. https://doi.org/10.1016/j.buildenv.2005.11.001

[30] Yao M, Zhang L, Ma J, et al. On airborne transmission and control of SARS-Cov-2. Science of The Total Environment, 2020, 731: 139178. https://doi.org/10.1016/j.scitotenv.2020.139178

[31] Biktasheva IV. Role of a habitat's air humidity in Covid-19 mortality. Science of the Total Environment, 2020, 736: 138763 . https://doi.org/10.1016/j.scitotenv.2020.138763

[32] Huang Z, Huang J, Gu Q, et al. Optimal temperature zone for the dispersal of COVID-19. Science of The Total Environment, 2020, 736: 139487. https://doi.org/10.1016/j.scitotenv.2020.139487

[33] Lyon A and Freer Y. Goals and options in keeping preterm babies warm. Archives of Disease in Childhood-Fetal and Neonatal Edition, 2011, 96(1): 71-74 https://doi.org/10.1136/adc.2009.161158

[34] Hassan MM, El Zowalaty ME, Khan SA, et al. Role of Environmental Temperature on the Attack rate and Case fatality rate of Coronavirus Disease 2019 (COVID-19) Pandemic. Infection Ecology \& Epidemiology, 2020, 10(1): 1792620. https://doi.org/10.1080/20008686.2020.1792620

[35] Fadaei A. Ventilation Systems and COVID-19 Spread: Evidence from a Systematic Review Study. European Journal of Sustainable Development Research, 2021, 5(2): em0158. https://doi.org/10.21601/ejosdr/10845

[36] Chinn RY and Sehulster L. Guidelines for environmental infection control in health-care facilities; recommendations of CDC and Healthcare Infection Control Practices Advisory Committee (HICPAC), 2003.

[37] Guo M, Xu P, Xiao T, et al. Review and comparison of HVAC operation guidelines in different countries during the COVID-19 pandemic. Building and Environment, 2020, 187: 107368. https://doi.org/10.1016/j.buildenv.2020.107368

[38] Noorimotlagh Z, Jaafarzadeh N, Martínez SS, et al. A systematic review of possible airborne transmission of the COVID-19 virus (SARS-CoV-2) in the indoor air environment. Environmental Research, 2020, 193: 110612 . https://doi.org/10.1016/j.envres.2020.110612

[39] Chen C, Zhao B, Yang X, et al. Role of two-way airflow owing to temperature difference in severe acute respiratory syndrome transmission: revisiting the largest nosocomial severe acute respiratory syndrome outbreak in Hong Kong. Journal of the Royal Society Interface, 2011, 8(58): 699-710. https://doi.org/10.1098/rsif.2010.0486

[40] Mousavi ES and Grosskopf KR. Ventilation rates and airflow pathways in patient rooms: A case study of bioaerosol containment and removal. Annals of Occupational Hygiene, 2015, 59(9): 1190-1199. https://doi.org/10.1093/annhyg/mev048

[41] Zhu S, Jenkins S, Addo K, et al. Ventilation and laboratory confirmed acute respiratory infection (ARI) rates in college residence halls in College Park, Maryland. Environment International, 2020, 137: 105537. https://doi.org/10.1016/j.envint.2020.105537

[42] Morawska L, Tang JW, Bahnfleth W, et al. How can airborne transmission of COVID-19 indoors be minimised? Environment International, 2020, 142: 105832. https://doi.org/10.1016/j.envint.2020.105832

[43] Escombe AR, Ticona E, Chávez-Pérez V, et al. Improving natural ventilation in hospital waiting and consulting rooms to reduce nosocomial tuberculosis transmission risk in a low resource setting. BMC Infectious Diseases, 2019, 19(1): 1-7. https://doi.org/10.1186/s12879-019-3717-9

[44] Sundell J, Levin H, Nazaroff WW, et al. Ventilation rates and health: multidisciplinary review of the scientific literature. Indoor Air, 2011, 21(3): 191-204. https://doi.org/10.1111/j.1600-0668.2010.00703.x 